\title{
Retraction Note to: LncRNA HCG11 regulates proliferation and apoptosis of vascular smooth muscle cell through targeting miR-144-3p/ FOXF1 axis in atherosclerosis
}

\author{
Yi Liu ${ }^{1}$, Xiyun Cui ${ }^{2}$, Cong Wang ${ }^{1}$ and Sihai Zhao ${ }^{3^{*}}$
}

\section{Retraction to: Biol Res (2020) 53:44}

https://doi.org/10.1186/s40659-020-00306-2

The authors have retracted this article because following verification, the results of the statistical analysis of the data presented in Fig. 4D and Fig. 6D were identified to be incorrect; specifically, the TUNEL assay results indicated that microRNA-144 could not reverse the effects of HCG11 on apoptosis, which affected the overall conclusions of the study.

All authors agree to this retraction.

\section{Author details}

'Department of Clinical Laboratory, The First Affiliated Hospital of Xi'an Jiaotong University, Xi'an 710061, Shaanxi, China. ${ }^{2}$ Department of Clinical Laboratory, Weapon Industry 206 Hospital, Xi'an 710061, Shaanxi, China. ${ }^{3}$ Laboratory Animal Center, Xi'an Jiaotong University School of Medicine, Xi'an 710061,

Shaanxi, China.

Published online: 09 September 2021

\section{Publisher's Note}

Springer Nature remains neutral with regard to jurisdictional claims in published maps and institutional affiliations.
The original article can be found online at https://doi.org/10.1186/s40659020-00306-2.

*Correspondence: sihai1569@126.com

${ }^{3}$ Laboratory Animal Center, Xi'an Jiaotong University School of Medicine, Xi'an 710061, Shaanxi, China

Full list of author information is available at the end of the article

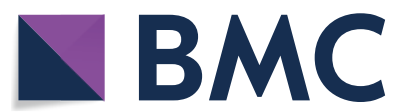

(c) The Author(s) 2021. Open Access This article is licensed under a Creative Commons Attribution 4.0 International License, which permits use, sharing, adaptation, distribution and reproduction in any medium or format, as long as you give appropriate credit to the original author(s) and the source, provide a link to the Creative Commons licence, and indicate if changes were made. The images or other third party material in this article are included in the article's Creative Commons licence, unless indicated otherwise in a credit line to the material. If material is not included in the article's Creative Commons licence and your intended use is not permitted by statutory regulation or exceeds the permitted use, you will need to obtain permission directly from the copyright holder. To view a copy of this licence, visit http://creativecommons.org/licenses/by/4.0/. The Creative Commons Public Domain Dedication waiver (http://creativecommons.org/publicdomain/zero/1.0/) applies to the data made available in this article, unless otherwise stated in a credit line to the data. 